\title{
SISTEM INFORMASI MODEL SUPERVISI KLINIK BERBASIS MANAJEMEN PENGETAHUAN DALAM MENINGKATKAN MUTU PEMBELAJARAN
}

\author{
Warda Indadihayati \\ Universitas Negeri Yogyakarta \\ e-mail: warda_indadihayati@uny.ac.id
}

\begin{abstract}
This study aims to develop a clinical supervision model based on proses knowledge management in improving the quality of learning. The research design uses research and development $(R \& D)$ with the stages of data collection, product planning and design, initial product development, product validation, revision of validation results, field trials, and revisions and final product improvements. Information system development outcomes at the stage (1) identification of potential teacher condition as supervisor; (2) implementation of supervision activities through pre-observation, observation and post-observation stages with clinical instruments that can be stored online; (3) the best practice of learning that can be accessed to share instructional innovations; (4) the existence of an online teacher performance appraisal archive.
\end{abstract}

Keywords: Clinical supervision model, knowledge management, quality learning

\begin{abstract}
Abstrak: Penelitian ini bertujuan mengembangkan model supervisi klinik berbasis proses manajemen pengetahuan dalam meningkatkan mutu pembelajaran. Rancangan penelitian menggunakan research and development (R\&D) dengan tahapan pengumpulan data, perencanaan produk dan desain, pengembangan produk awal, validasi produk, revisi hasil validasi, uji coba lapangan, dan revisi dan penyempurnaan produk akhir. Hasil pengembangan sistem informasi pada tahapan (1) identifikasi kondisi guru yang berpotensi sebagai supervisor; (2) pelaksanaan kegiatan supervisi melalui tahapan pre-observation, observation, dan post-observation dengan instrumen secara klinik yang dapat terseimpan secara online; (3) adanya best practise pembelajara yang dapat diakses untuk membagi inovasi pembelajaran; (4) adanya arsip penilaian kinerja guru secara secara online.
\end{abstract}

Kata kunci: Supervisi klinik, proses manajemen pengetahuan, mutu pembelajaran

Perkembangan teknologi dan informasi pada abad 21 merupakan tantangan dalam dunia pendidikan untuk mempertahankan mutunya. Komponen utama penjaminan mutu pendidikan dengan pembinaan guru di sekolah adalah meningkatkan kualitas pembelajarannya. Dengan kata lain mutu pendidikan erat kaitannya dengan profesionalisme guru. Terkait hal tersebut maka supervisi pembelajaran menjadi kegiatan penting yang harus dilaksanakan dalam upaya memperbaiki mutu pembelajaran.Usaha meningkatkan mutu pendidikan dan pengajaran sebagian besar terletak pada peningkatan kegiatan guru dalam mendorong siswa kearah tercapainya tujuan. Agar tugas mendidik dan mengajar dapat ditingkatkan, guru perlu mendapat pembinaan berupa pengertian mengenai pentingnya fungsi supervisi pendidikan. Usaha yang demikian tidak dapat dipisahkan dari peran kepala sekolah yang harus mampu membina guru agar peduli terhadap perubahan serta bersikap inovatif dan selalu mengembangkan kualitas sumber daya dalam mengajar dan mendidik. Dalam hal ini, dijelaskan jika, "Quality in education has always been measured on quality of content in curriculum and how well such fits present and future needs of learners. The new concept of dimensions in quality relates to 'quality learners' among other dimensions" (Adebayo, 2009). Penjelasan tersebut dapat dipahami jika kualitas pendidikan dapat diukur dari kualitas konten dalam kurikulum dan seberapa baik cocok diterapkan di masa sekarang untuk kebutuhan yang akan datang bagi siswa. 
Sedangkan dalam hal lain dijelaskan jika "Supervision ... to help the teacher improve his or her instructional performance" (Acheson \& Gall, 1980). Hal ini dapat dipahami jika supervisi menekankan pada bantuan memperbaiki pelaksanaan pengajaran guru "The effect of supervisi klinik towards teaching performance of teachers and those findings shows that supervisi klinik is still needed because the teachers have not reached the level of being dynamic, knowledgable and skill full' (Veloo et al., 2013). Dapat dipahami jika pengaruh supervisi klinik terhadap kinerja mengajar guru dan temuannya menunjukkan bahwa supervisi klinik masih diperlukan karena para guru belum mencapai tingkat dinamis, kemampuan pengetahuan dan keterampilan yang penuh.

Sejalan dengan hal di atas, di sisi lain perkembangan ilmu pengetahuan dan tehnologi dalam era globalisasi sekarang ini berjalan begitu cepat. Kemampuan suatu lembaga atau instansi akan dua hal tersebut menjadi salah satu faktor daya saing yang sangat penting. Ketika suatu lembaga terutama bergerak di bidang pendidikan ingin meningkatkan kualitasnya, maka dibutuhkan tingkat pengetahuan yang sangat luas pada setiap sumber daya manusia (SDM) yang ada sehingga mampu untuk berkompetisi dan menunjukkan eksistensinya. Kondisi kompetisi yang semakin ketat seperti sekarang ini menyebebkan perlu adanya perubahan paradigma dari resource-based competitivenes menjadi mengandalkan knowledge based competitiones. Kedua konsep ini sangat bertolak belakang, dimana konsep pertama bertumpu pada sumber daya alam, lokasi dan kondisi geografis. Sedangkan konsep kedua berdasarkan pada ilmu pengetahuan dan tehnologi (IPTEK) serta pengembangan sumber daya manusia (SDM). Untuk memudahkan pengembangan sumber daya manusia suatu lembaga diperlukan kemampuan untuk mengelola dan mengembangkan knowledge yang dimiliki. Pengelolaan knowledge tersebut pada akhirnya dapat menjadi dukungan yang handal bagi suatu lembaga untuk meningkatkan daya saingnya.
Pelaksanaannya kegiatan supervisi klinik berbasis proses manajemen pengetahuan ini dilakukan dengan kegiatan supervisi yang mencerminkan hubungan kesejawatan antara supervisor dengan guru. Oleh karena itu, tahapan pertama yang harus dilakukan oleh kepala sekolah adalah mengidentifikasi guru yang berpotensi menjadi supervisor. Dalam hal ini level abstraksi dan level komitmen guru yang dibagi menjadi empat kuadran yang dapat dijadikan dasar dalam indentifikasi kondisi guru (Glickman, 1981). Diantaranya pada (a) level kominten mengidentifikasikan komitmen rendah kondisi sedikit perhatian terhadap siswanya, sedikit waktu dan tenaga yang dikeluarkan, perhatian utama mempertahankan jabatan serta komitmen tinggi diidentifikasi sebagai kondisi tiggi perhatian terhadap siswanya, banya tenaga dan waktu digunakan dan bekerja sebanyak mungkin untuk orang lain; (b) level abstraksi membagi kondisi pada tiga tingkatan diantaranya yang pertama abstraksi rendah dengan kondisi bingung menghadapi masalah, tidak mengetahui cara bertindak bila menghadapi masalah, suka meminta petunjuk sedangkan tingkatan kedua adalah sedang dengan kondisi dapat mencegah masalah, dapat menafsirkan satu atau dua alternatif pemecahan masalah, sulit merencakan pemecahan masalah secara komprehensip. Selanjutanya kondisi abstraksi tinggi yaitu dapat memecahkan permasalahan dari berbagai perspektif, dapat mengeneralisasikan berbagai alternatif pemecahan masalah serta dapat memilih rencana dan memikirkan setiap langkah.

Tingkatan tersebut kemudian dapat ditafsirkan dalam empat kuadran, yaitu kuadran I dengan kondisi tingkat abstraksi dan komitmen rendah yang disebut dengan teacher dropout, kuadran II dengan kondisi level komitmen tinggi dan level abstraksi rendah yang disebut unfocused worker, selanjtnya kuadran III menunjukkan tingkat komitmen rendah dan abstraksi tinggi dengan sebutan teacher intelligent, sedangkan kuadran terahir pada kuadran IV dengan kondisi tingat level komitmen dan abstraksi tinggi atau disebut dengan guru professional. Tingkatan 
kuadran kondisi guru pada kuadran IV dengan katogori guru profional dapat dijadian rujukan bagi kepala sekolah untuk memilih guru tersebut sebagai supervisor bagi guru mata pelajaran atau guru lainnya. Hal ini yang menjadi proses awal dalam managemen pengetahuan yang diharapkan guru yang profesional mampu mengembangkan kompetensi bagi guru lain dalam hal inovasi pembelajaran.

Pemilihan uji coba pengembangan sistem informasi di SMP Negeri 5 kota Malang karena dalam penjaminan mutu layanan pengajaran, sekolah menjadikan program supervisi pembelajaran setiap tahunnya kepada guru di sekolah. Namun dalam pelaksanaannya kepala sekolah tidak ikut penuh dalam mensupervisi gurugurunya, namun kepala sekolah hanya mensupervisi guru yang sudah profesional dalam arti yang memiliki kemampuan yang lebih menonjol. Kemudian guru-guru tersebutlah yang melakukan supervisi terhadap guru lainnya. Dari karakteristik tersebutlah peneliti menjadikan sekolah sebagai objek uji coba produk pengembangan, karena konsep pelaksanaan di sekolah sesuai dengan karakteristik model yang akan dikembangkan. Selain itu, karena sekolah belum menjadikan hasil supervisi sebagai arsip dalam pengembangan guru kerena kesulitas dalam pengerjaannya, sehingga dengan adanya pengembangan sistem informasi model supervisi klinik berbasis proses manajemen pengetahuan diharapkan sekolah menjadikan arsip setiap inovasi pembelajaran yang dilakukan di sekolah dari hasil supervisi pembelajarannya. Karena model ini menghasilkan produk berupa sistem informasi untuk pemetaan kemampuan guru dan tindakan untuk meningkatan kemampuan guru.

Orientasi pengembangan ini yang akan dilakukan dengan istrumen mengenai karakteristik guru langsung pada programnya, kemudian dari hasil tersebut akan dapat langsung tersimpan. Arsiparsip kondisi guru dan cara pengembangan kemampuan sesuai dengan kondisi guru tersebut dapat dijadikan acuan bagi jajaran kepemimpinan untuk mengarahkan pengembangan dan inovasi pembelajaran oleh guru. Penelitian pengembangan yang akan dilakukan ini menitik beratkan pelaksanaan supervisi pembelajaran dengan pendekatan klinik berbasis proses manajemen pengetahuan di sekolah, dalam upaya meningkatkan mutu pembelajaran yang merupakan salah satu aspek penting dalam mutu pendidikan di sekolah. Karena keterbatasan kepala sekolah, dalam hal ini diperlukan pengembangan berupa model untuk pelaksanaan kegiatan supervisi yang akan dilakukan di sekolah. Sehingga penelitian ini bertujun untuk mendiskripkan (1) konsep awal pengembangan sistem informasi (2) proses pengembangan sistem informasi (3) faktor pendukung dan penghambat pengembangan sistem informasi (4) alternatif cara mengatasi faktor penghambat.

\section{METODE}

Penelitian dan pengembangan (R\&D) yang dilakukan bertujuan untuk menghasilkan produk dengan menyempurnakan produk yang telah ada, dalam hal ini Wiyono (2007:9) secara konseptual mengemukakan penelitian dan pengembangan (R\&D) adalah penelitian yang bertujuan untuk mengembangkan dan menghasilkan suatu produk, program, atau model suatu kegiatan tertentu. Model penelitian dan pengembangan ini mengikuti model pengembangan yang yang terdiri atas sepuluh tahapan menjadi tujuh tahapan (Borg \& Gall, 1983).

Pertama tahap penelitian pendahuluan, peneliti melakukan studi literatur yang berkaitan dengan permasalahan pengembangan sistem informasi model supervisi klinik berbasis proses manajemen pengetahuan dalam upaya meningkatkan mutu pembelajaran. Analisis kebutuhan model ini dilakukan dengan studi litelatur tentang model pengembangan supervisi klinik yang sudah ada serta model-model penelitian terkait dengan proses manajemen pengetahuan, kemudian melakukan pengukuran kebutuhan model yang akan dikembangkan disesuaikan dengan kondisi di SMP Negeri 5 kota Malang dengan analisis SWOT (strength, weakness, opportunity, threat) untuk mengetahui aspek-aspek yang diperlukan dalam pengembangan produk yang akan 
dilakukan, sehingga pada tahap ini peneliti menggunakan teknik wawancara, observasi dan dokumentasi.

Tahapan selanjutnya adalah perencanaan produk dan desain dimana hasil analisis SWOT yang telah dilakukan, peneliti menyusun rencana penelitian yang meliputi merumuskan tujuan yang akan dicapai pada setiap tahapan dalam model yang dikembangkan, pengumpulan bahan materi pengembangan sistem informasi, serta membuat konsep awal rancangan produk.

Pengembangan produk awal dengan produk yang disusun dan dirancang secara sederhana sehingga memudahkan pengguna dalam memanfaatkannya. Dalam proses perancangan model didesain dengan panduan yang komunikatif untuk dapat langsung dipraktekkan di sekolah berupa buku panduan penggunaan program. Kemudian pembuatan kisi-kisi dan instrumen penilaian produk.

Tahap validasi ahli, produk awal yang sudah disusun selanjutnya dievaluasi oleh ahli untuk penyempurnaan berupa kritik dan saran sebagai bahan perbaikan lebih lanjut. Data yang terjaring dianalisis secara diskriptif untuk melihat kecenderungan jawaban responden. Interprestasi skor dalam skala Linkert berisi empat unsur yaitu (1) kelayakan produk (2) jumlah skor yang diperoleh (3) jumlah keseluruhan skor ideal dalam satu item (4) konstanta/100\%. Dengan rumus interprestasi skor kelayakan produk:

$$
K P=\frac{x}{x 1} \times 100 \%
$$

Keterangan:

$\mathrm{KP}=$ Kelayakan produk

$\mathrm{X} \quad=$ Jumlah skor yang diperoleh

$\mathrm{X}_{1}=$ Jumlah keseluruhan skor ideal

dalam satu item.

Konversi tingkat vallidasi berdasr kriteria interperstasi skor kelayakan produk dapat dilihat pada Tabel 1.

Prakteknya, uji coba produk melibatkan para ahli (experts) ahli yang terlibat dalam proses evaluasi adalah ahli supervisi dari jurusan Manajemen Pendidikan, ahli pembuatan model (sofware) dari jurusan Teknik Informatika.
Revisi hasil validasi ahli, dilakuakn dengan rekapitulasi hasil validasi yang telah dilakukan oleh para ahli, produk direvisi sesuai catatan-catatan perbaikan dan saran-saran dari validator ahli. Hal tersebut dilakukan sebagai acuhan peneliti dalam menganalisis dan merevisi komponen-komponen apa saja dalam produk yang direvisi. Hasilnya kemudian digunakan uji produk di lapangan. Harapannya agar dari produk yang telah direvisi tersebut dapat lebih baik, efektif, dan efisien penggunaannya.

Uji coba lapangan, pengembangan produk yang telah direvisi oleh para ahli kemudian diuji cobakan di sekolah dengan melibatkan pihak sekolah untuk menelaah produk guna validasi kelayakan produk. Dalam hal ini uji lapangan dilakukan oleh kepala sekolah, wakil kepala sekolah dan guru sebagai responden dalam penggunaan model yang dikembangkan.

Revisi dan penyempurnaan, tahapan ini dilakukan sebagai tindak lanjut uji produk, sesuai dengan saran-saran yang diberikan oleh tenaga ahli isi, ahli media dan hasil uji lapangan sebagai penyempurnaan produk yang ada. Tahap ini merupakan kegiatan akhir dari kegiatan penelitian dan pengembangan yang dilakukan.

Teknik analisis data yang digunakan penelitian ini menggunakan dua metode analisis, menjelaskan jika triangulasi konkuren dilakukan untuk membandingkan dua database untuk mengetahui konvergensi, perbedaan-perbedaan, atau beberapa kombinasi. Strategi pencamuran ini terjadi ketika peneliti sampai pada tahap interprestasi dan pembahasan (Creswell, 2014). Hal ini dapat dilihat pada Bagan 1.

\section{HASIL}

Hasil penelitian pengembangan yang dilakukan sesuai dengan tahapan yang dilakukan yaitu pertama mengenai perencanaan model dilakukan dengan memahami da mendiskripsikan konsep awal pengembangan sistem informasi yang dilakukan studi literatur mengenai pengembangan model yang sudah ada sebelumnya dan proses manajemen pengetahuan. Kemudian melakukan identifikasi karakteristik tempat uji coba produk di SMP Negeri 5 kota Malang, hasil dari identifikasi tersebut didapat dari hasil 
analisis SWOT dengan mengetahui peluang penerapan model di sekolah. Sehingga pengembangan model yang dilakukan dapat dilihat pada Bagan 2.

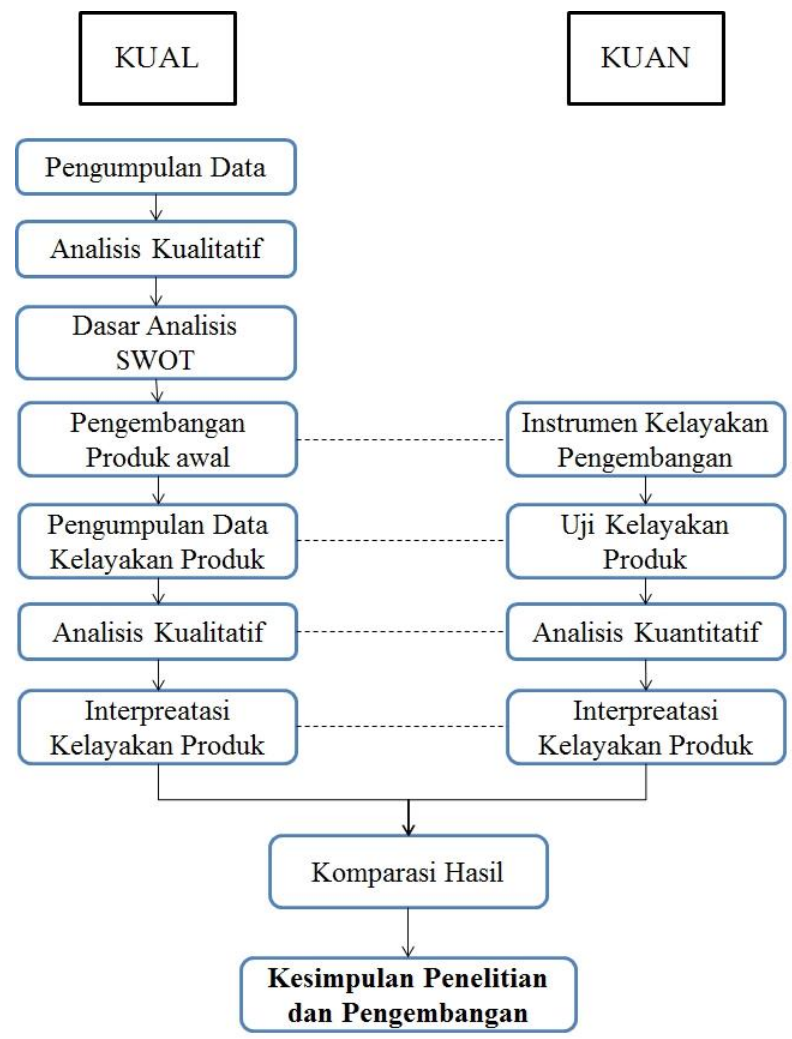

\section{Bagan 1. Tahapan Analisis Data Penelitian dan Pengembangan Modifikasi Creswell (2014)}

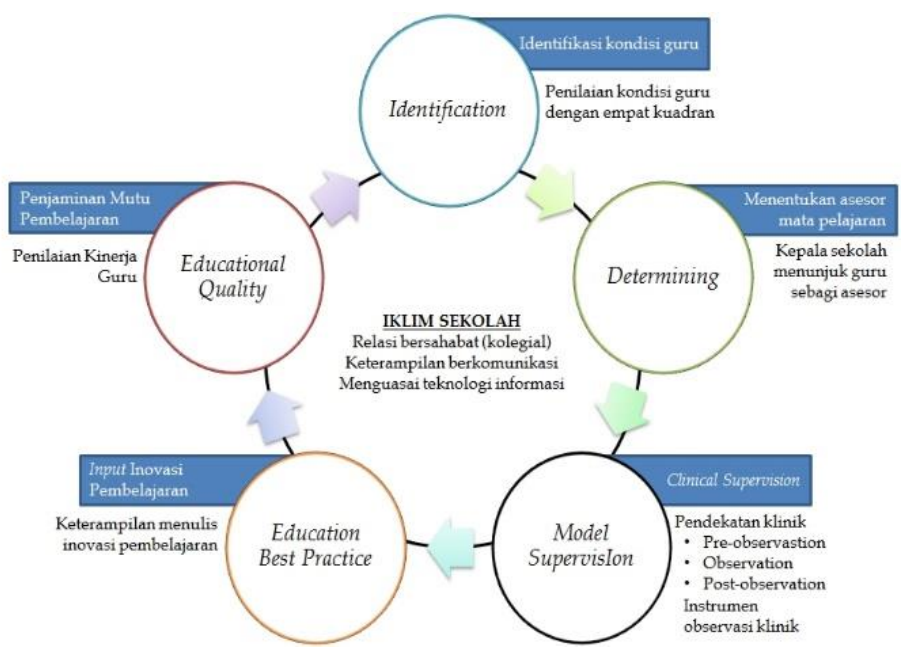

Bagan 2. Model Pengembangan Sistem Informasi Supervisi klinik Model Berbasis Proses manajemen pengetahuan dalam Meningkatkan Mutu Pembelajaran

Konsep pengembangan pada Bagan 2 tersebut kemudian dijadikan bahan dalam membuat media untuk mengaplikasikan pelaksaan pengembangan sistem informasi. Hasil dari pengembangan tersebut kemudia diuji kevalidannya melalui uji ahli oleh dosen ahli supervisi dari jurusan manajemen pendidikan, dosen ahli TI dari jurusan Teknik Informatika dan dosen ahli media dari jurusan Tehnologi pembelajaran, selanjutnya dilakukan uji lapangan skala kecil dan uji lapangan skala besar di SMP Negeri 5 kota Malang

\section{PEMBAHASAN \\ Konsep Awal Pengembangan Model}

Penentuan konsep awal pengembangan produk yang dilakukan menggunakan pengumpulan data secara kualitatif dengan studi literatur terkait dasar awal pengembangan model yang ada karena pengembangan yang dilakukan bertujuan untuk memperbarui model yang sudah ada sebelumnya. Hasil studi dilteratur didapatkan kesimpulan bahwasannya model pengembangan ini didasarkan atas pengembangan model supervise klinik yang masih terdapat beberapa kelemahan dalam pelaksanaannya, yaitu kurang efisiensinya pelaksanaan supervisi dari segi waktu, tenaga dan biaya. Kemudian hasil temuan mengenai rekomendasi penerapan knowledge management di sekolah untuk mengaplikasikan model temuan tersebut dalam program sekolah yang lebih spesifik, dari hasil tersebutlah peneliti ingin memofikasi model yang sudah ada, dengan menggunakan proses manajemen pengetahuan dalam alur supervisi klinik di sekolah (Ferdinandus et al., 2015).

Hasil dari teknik pengumpulan data tersebut kemudian dianalisis dengan kondensasi data, yaitu dalam hal ini dilakukan dengan menyederhanakan hasil temuan yang disajikan dalam Tabel 2 .

Temuan pada table 2, diinterprestasikan bahwa SMP Negeri 5 kota Malang memiliki karakteristik yang diperlukan guna pelaksanaan uji coba produk di lapangan. Hasil tersebut juga digunakan dalam pengembangan produk agar dapat teraplikasikan di sekolah, karena pengembangan model ini dikhususkan pada sistem persekolahan. Dalam pengembangan ini untuk menentukan potensi guru sebagai supervisor dikembangkan penilaian guru dalam empat kuadran yang mengidentifikasi guru dalam 
empat kuadran yaitu guru droupout pada kuadran I, guru unfocused worker pada kuadran II, teacher intelligent pada kuadran III dan guru peofesional pada kuadran IV (Glickman, 1981). Dalam pengembangan model ini guru yang berada pada kuadran IV merupakan guru yang berpotensi sebagai supervisor bagi guru mata pelajaran. Dengan demikian guru dalam kuadran ini diindikasikan memiliki keterampilan dan kompetensi yang lebih baik karena dalam kegiatan supervisi diperlukan keterampilan guru dalam pelaksanaannya agar guru tidak merasa terawasi namun sebaliknya pada kegiatan dalam batuan. Hal ini juga sesuai dengan penjelasan jika supervision is the provided for purpose of improving teaching and learning. The effectiveness of supervision depends on the skills and competency of the supervisions in working with the entire staff classroom teacher, specialist and administrators alike (Mantja, 2000). Bahwasannya supervisi disediakan untuk meningkatkan pengajaran secara efektif yang bergantung pada keterampilan dan kompetensi supervisor.

Kegiatan supervisi harus difokuskan pada kegiatan pembelajaran yang dalam hal ini dijelaskan jika "Supervision is a service particulary concerned with instruction and it's improvement. It is directly concerned with teaching and learning and with factors included in and related to these process - teaches, pupils, curriculum, material of instruction social ophusical environment of the situation" (Adam \& Dicky, 1953). Dapat dipahami jika kegiatan supervisi menekankan dalam bentuk pelayanan degan sasaran utama supervisi adalah mengar dalam usaha untuk memperbaiki. Oleh karena itu, pengembangan supervisi dalam hal ini pada instrumen pelaksanaan supervisi yang harus secara klinik untuk memberikan kesepatan antara guru dan supervisor dalam melakukan pengamatan untuk meningkatkan atau menguatkan kompetensi guru yang lemah.

Instrumen secara klinik yang dikembangkan didasarkan pada perencanaan, pelaksanaan dan evaluasi pembelajaran, yang sesuai dengan artikel Educational and Training Inspectorate menyetakan bahwa "Criteria for effective teaching and learning (a) planning for improvement; (b) teaching and learning strategirs; (c) classroom management; (d) monitoring and evaluation of learning" (Matchhett, 2005). Dapat dipahami bahwa kriteria pengajaran dan pembelajaran yang efektif meliputi perencanaan perbaikan, strategi belajar mengajar, manajemen kelas, serta evaluasi pembelajaran.

Pengembangan manajemen pengetahuan selanjutnya pada best practise pembelajaran untuk membantu guru-guru di sekolah dalam menyebarkan pengetahuan mengenai peningkatan pembelajaran di sekolah. Kegiatan ini dilakukan untuk menyimpan aset-aset pengetahuan dalam organisasi. Pengertian manajemen pengetahuan yaitu "Knowledge management is the planning, organizing, motivating, and controlling of people, processes and systems in the organization to ensure that its knowledgerelated assets are improved and effectively employed' (King 2009). Bahwasannya manajemen pengetahuan adalah perencanaan, pengorganisasian, memotivasi, dan mengendalikan orang, proses dan sistem dalam organisasi untuk memastikan bahwa aset-aset terkait pengetahuan ditingkatkan dan efektif digunakan. Dengan adanya pemilihan guru yang berpotensi sebaga supervisor akan menumbuhkan motivasi guru dalam melakukan perbaikan-perbaikan mengajar. Penemuan perbaikan mengajar itu dapat dibagikan ke guru lainnya melalui komponen best practise ini. Hal ini sesuai dengan report United Nasional Childern's Fund bahwasannya "Professional development can help overcome shortcomings that may have been part of teachers' pre-service education and keep teachers abreast of new knowledge and practices in the field" (WHO, 2000). Dapat difahami jika pengembangan profesional dapat membantu mengatasi kekurangan yang mungkin telah menjadi bagian dari pendidikan pre-service guru dan menjaga guru mengikuti pengetahuan dan praktekpraktek baru di lapangan.

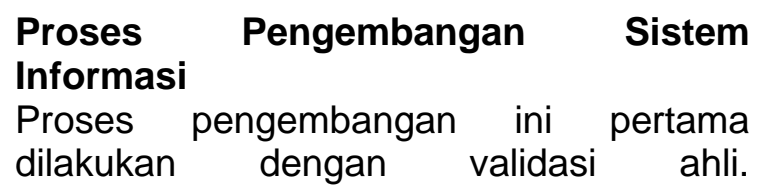


Rekapitulasi hasil penilaian dengan angket terbuka menginterprestasikan hasil masukan dan saran pada penilaian kelayakan produk, yang dilakukan dengan wawancara dan hasil angket yang diberikan. Diantaranya pada penilaian kelayakan materi, revisi yang dilakukan pada instrumen observasi secara klinik yang diungkapkan oleh kedua ahli uji materi yaitu pada menambahan dan menspesifikkan istrumen dengan perkembangan teori yang ada. Dalam hal ini peneliti menggunakan aspek pada instrumen supervisi dengan membagi menjadi tiga aspek yang digunakan dalam pembelajaran, yaitu perencanaan pembelajaran, pelaksanaan pembelajaran dan evaluasi pembelajaran. Setiap aspek tersebut memiliki kriteria-kriteria tersendiri megingat kegiatan supervisi yang dilakukan di sekolah ditujukan untuk semua guru baik guru yang sudah berpengalaman maupun guru baru. Sehingga instrumen penilaiannya juga harus beragam. Kegiatan supervisi klinik harus disertakan dengan RPP yang disepakati untuk dilakukan observasi. Penambahan RPP ini dilakukan dengan menambahkan menu RPP untuk kegiatan upload RPP oleh seluruh guru di sekolah. Perbaikan materi selanjutnya pada menu post-observation yang harus dilakukan dengan pemecahan masalah oleh pihak guru dan supervisornya. Dalam hal ini peneliti memperbaiki pada penambahan kolom komentar untuk guru pada menu post-observation. Sedangkan hasil analisis pada uji ahli media dilakukan perbaikan pada buku panduan dan sistem informasi pengembagan model, dilakukan pada warna baground latar pada sistem informasi sedangkan pada buku panduan mengganti cover, font, penataan judul dan keterbacaan gambar yang dicetak. Hasil perolehan skor tiap aspek penilaian kelayakan produk tersebut kemudian direkapitulasi untuk mengetahui kelayakannya, diantaranya dapat dilihat pada Tabel 3.

Hasil perolehan pada Tabel 3 menunjukkan jika rata-rata persentase kelayakan produk pada uji lapangan skala kecil adalah 93,72\% dengan kualifikasi sangat layak. Selanjutnya komentar dan saran pada instrumen penilaian bertujuan untuk melihat sejauh mana tanggapan responden pada perbaikan penggunaan produk di lapangan. Sedangkan analisis kualitatif hasil uji lapangan skala keci dilakukan dengan menginterprestasikan masukan-masukan yang diberikan oleh responden pada kegiatan ini, yaitu saran perbaikan pada pemberian menu upload untuk PKG agar sewaktu-waktu dapat digunakan dan penambahan persentase kondisi guru di sekolah sesuai dengan empat kuadran yang ada dalam menu pengembangan sistem informasi.

Hasil perhitungan pada tiap apek penilaian pengembangan sistem informasi tersebut kemudian direkapitulasi untuk mengetahui tingkat kelayakan produk pengembangan hari hasil uji lapangan skala besar, yang dapat dilihat pada Tabel 4.

Hasil perolehan pada Tabel 4 menunjukkan jika perolehan rata-rata persentase kelayakan produk adalah 81,6 persen denngan kategori jika produk yang dikembangakan dinilai sangat layak oleh responden.

\section{Faktor Pendukung dan Penghambat Sistem Informasi}

Identifikasi faktor pendukung dan penghambat pengembangan ini dilakukan secara kualitatif dengan menginterprestasikan hasil wawancara di lapangan saat melakukan uji coba produk. Sehingga dapat diketahui hasil identifikasi faktor pendukung penggunaan pengembangan ini yaitu pada kebutuhan sekolah akan aspek-aspek yang dikembangkan diantaranya kebutuhan akan (a) penilaian kondisi guru secara objektif untuk menentukan guru yang berpotensi sebagai supervisor; (b) pengarsipan data peningkatan kondisi guru melalui supervisi klinik; (c) best practise pembelajaran; (d) pengarsipan data hasil PKG. Fator penghambat pada penerapan model melalui software ini dapat diidentifikasi menjadi dua yaitu pada masalah tehnis dan pengguna (user). Untuk masalah tehnis pada (a) aplikasi ini tergantung pada jaringan internet; (b) alamat susah ditemukan. Sedangkan faktor pada user diantaranya masih awamnya penggunaan aplikasi secara online khususnya pada guru-guru senior. 


\section{Alternatif Cara Mengatasi Faktor Penghambat Pengembangan Sistem Informasi}

Faktor penghambat dalam menjalakan sistem informasi ini perlu memiliki alternatif pada untuk mengatasinya. Diantaranya cara mengatasi faktor penghambat secara teknis dengan menjalin hubungan kolegian dalam penggunaan aplikasi pengembangan model sehingga jika terjadi masalah pada jaringan internat kegiatan supervisi tetap berlagsung namun input data dilakukan jika jaringan internet sudah stabil. Faktor penghambat dari pengguna yang belum terbiasa dengan penggunaan aplikasi secara online dapat dilakukan dengan mensosialisasikan pengembangan model ini secara terus menerus yang dilengkapi dengan buku panduan yang penggunaan program yang mudah di akses hal ini sebagai upaya dalam memaksimalkan pemanfaatannya, sehingga akan menjadi kebutuhan guruguru dalam penggunaan aplikasi pengembangan ini.

Tabel 1. Skala Penilaian Produk

\begin{tabular}{lll}
\hline Tingkat Ketercapaian & \multicolumn{1}{c}{ Kualifikasi } & \multicolumn{1}{c}{ Keterangan } \\
\hline $81 \%-100 \%$ & Sangat layak & Tidak perlu revisi \\
$61 \%-80 \%$ & Layak & Tidak perlu revisi \\
$41 \%-60 \%$ & Cukup layak & Revisi \\
$21 \%-40 \%$ & Kurang layak & Tidak dapat digunakan \\
$0 \%-20 \%$ & Sangat tidak layak & Gagal/tidak digunakan \\
\hline
\end{tabular}

Sumber: Modifikasi dari (Akdon \& Hadi, 2005)

Tabel 2. Temuan Lapangan Hasil Analisis Studi Awal

\begin{tabular}{ccc}
\hline No. & Komponen & Hasil Temuan \\
\hline 1. & $\begin{array}{c}\text { Pelaksanaan supervisi di } \\
\text { sekolah }\end{array}$ & $\begin{array}{c}\text { Pelaksanaan supervisi di sekolah dilakukan dengan tahapan pertemuan } \\
\text { awal, observasi dan pertemuan balikan }\end{array}$ \\
\hline 2. & $\begin{array}{c}\text { Proses manajemen } \\
\text { pengetahuan }\end{array}$ & $\begin{array}{c}\text { Menentukan beberapa guru sebagai asesor di tiap mata pelajaran. } \\
\text { Bertukar pengalaman inovasi pembelajaran denngan kegiatan supervisi }\end{array}$ \\
\hline 3. & $\begin{array}{c}\text { Dampak supervisi terhadap } \\
\text { mutu pembelajaran }\end{array}$ & $\begin{array}{c}\text { Perbaikan pengajaran guru dalam pengelolaan kelas } \\
\text { Perbaikan mengajar guru sesuai dengan penilaian kinerja guru (PKG) }\end{array}$ \\
\hline 4. & Jenis pembinaan guru & $\begin{array}{c}\text { Dilakukan secara individu oleh supervisor dengan guru dan secara } \\
\text { kelompok dengan mendatangkan narasumber dari luar sekolah. }\end{array}$ \\
\hline
\end{tabular}

Tabel 3. Rekapitulasi Penilaian Kelayakan Produk

\begin{tabular}{|c|c|c|c|}
\hline No. & Indikator Penilaian & Rentan Persentase & Skor Perolehan \\
\hline 1. & Pentingnya Pengembangan Model & $0-100$ & $96 \%$ \\
\hline 2. & Kualitas Penggunaan Materi & $0-100$ & $90,6 \%$ \\
\hline 3. & Kelayakan Media & $0-100$ & $92 \%$ \\
\hline 4. & Kebermanfaatan Penggunaan & $0-100$ & $96 \%$ \\
\hline 5. & Kemudahan Penggunaan & $0-100$ & $94 \%$ \\
\hline \multicolumn{3}{|c|}{ Total Skor } & $468,6 \%$ \\
\hline \multicolumn{3}{|c|}{ Rata-rata } & $93,72 \%$ \\
\hline
\end{tabular}

Tabel 4. Rekapitulasi Penilaian Kelayakan Produk Uji Lapangan Skala Besar

\begin{tabular}{cccc}
\hline No. & Indikator Penilaian & Rentan Persentase & Skor Perolehan \\
\hline 1. & Pentingnya Pengembangan Model & $0-100$ & $84,84 \%$ \\
2. & Kualitas Penggunaan Materi & $0-100$ & $80,31 \%$ \\
3. & Kelayakan Media & $0-100$ & $82,31 \%$ \\
4. & Kebermanfaatan Penggunaan & $0-100$ & $80,74 \%$ \\
5. & Kemudahan Penggunaan & $0-100$ & $80,21 \%$ \\
\hline \multicolumn{4}{r}{ Total Skor } \\
\hline
\end{tabular}

\section{KESIMPULAN}

Konsep awal pengembangan sistem informasi berawal dari hasil studi literatur mengenai beberapa model pengembangan supervisi klinik yang ada sebelumnya kemudian peneliti melakukan studi awal di lapangan untuk mengetahui karakteristik sekolah tempat uji coba produk yang akan dilaksanakan dengan analisis SWOT untuk mengetahui peluang terlaksananya 
pengembangan sistem informasi. Proses pengembangan sistem informasi ini didasarkan dari hasil analisis SWOT yang kemudian diuji validitaskan kepada para ahli yaitu ahli supervisi dari jurusan manajemen pendidikan, ahli TI dari jurusan Teknologi Informatika dan ahli media dari jurusan Teknologi Pembelajaran. Setalah divalidasi oleh ahli kemudian produk yang dikembangkan diuji cobakan di lapangan melalui dua siklus yaitu uji coba lapangan ska kecil dan uji coba lapangan skala besar. Dari hasil uji ahli dan uji lapangan kemudian produk pengembangan berupa sistem informasi supervisi klinik disempurnakan berdasarkan saran-saran yang ada. Sehingga diperoleh data mengenai faktor pendukung dan pengenghambat pengembangan sistem informasi, diantaranya faktor pendung pengembangan ini karena kebutuhan sekolah akan pengembangan sistem informasi yang dilakukan untuk mengarsipkan data-data terkait peningkatan kompetensi guru dalam mengajar. Sedangkan faktor penghambat pelaksanaan sistem informasi ini karena bergantung pada jaringan internet dan pengguna (user) yang belum terbiasa menggunakan aplikasi secara online. Oleh karena itu, untuk mengatasi faktor penghambat tersebut alternatif penyelesaian masalah dengan terus mensosialisakan penggunaan aplikasi ini agar lebih familiar dan terus digunakan, mengingat pelaksanaan secara supervisi klinik penting dilakukan salah satunya untuk menjamin kompetensi pengajaran guru di kelas dalam upaya meningkatkan mutu pendidikan.

\section{SARAN}

Saran pemanfaatan ditujukan pada sekolah-sekolah untuk memanfaatkan pengembagan sistem informasi model supervisi klinik berbasis manajemen pengetahuan dalam upaya meningkatkan mutu pembelajaran. Karena aplikasi ini dikembangkan untuk memudahkan sekolah dalam mengarsipkan data pengembangan kompetensi pengajaran guru secara online, sehingga dapat lebih memudahkan sekolah dalam melaksanakan kegiatan supervisi pembelajaran.

\section{DAFTAR RUJUKAN}

Acheson, K. A., \& Gall, M. D. (1980). Techniques in the supervisi klinik of Teachers, Perspective and Inservice Application. Longman, Inc.

Adebayo, J. (2009). Improving Pupils Quality Through Community Advocacy: The Role Of School Based Management Committee (SBMC). Journal of International Social Research, 2(8), 287-295. www.sosyalarastirmalar.com/cilt2/sayi 8pdf/ogundele_adelabu.pdf

Akdon, \& Hadi, S. (2005). Aplikasi Statistik dan Metode Penelitian untuk Administrasi dan Manajemen. Bandung.

Borg, \& Gall. (1983). Educational Research (An Introduction). Longman, Inc.

Creswell, J. W. (2014). Research Desain (Pendekatan Kualitatif, Kuantitatif, dan Mixed). Pustaka Pelajar.

Ferdinandus, E., Imron, A., \& Supriyanto, A. (2015). Knowledge Managament pada Sistem Persekolahan. Jurnal Pendidikan Humaniora, 3, 106-115. journal.um.ac.id/index.php/jph/ article/view/4853

Glickman, C. D. (1981). Development Supevision: Altenatif Practices for Helping Improve Instruction. ASCD.

Mantja, W. (2000). Model Pembinaan Supervisi Pengajaran. Malang: Program Pasca Sarjana Universitas Negeri Malang. Program Pasca Sarjana Universitas Negeri Malang.

Matchhett, M. J. (2005). Education and Training Inspectorate (pp. 6-7). http://dera.ioe.ac.uk/8660/1/thereflective-teacher.pdf

Veloo, Mary, \& Rozalina. (2013). The effects of supervisi klinik on the teaching performance of secondary school teachers. Sociall and Behavioral Sciences, 93, 35-39. www.sciencedirect.com/science /article/pii/S1877042813032515/pdf? md5

WHO. (2000). The state of the world's children. https://www.unicef.org/sowc/archive/E $\mathrm{NGLISH} / \mathrm{The}$ State of the World\%27s Children 2000.pdf 